\title{
Do vídeo à denúncia: representação do estupro coletivo no Twitter e estratégias discursivas
}

\author{
Viviane de Melo Resende ${ }^{1}$ \\ Nair Rabelo 2 \\ Departamento de Linguística, Universidade de Brasília, DF, Brasil
}

Resumo: Com base na abordagem teórico-metodológica da Análise de Discurso Crítica (ADC), este artigo propõe investigação acerca de discursos sobre violência contra mulheres, manifestos na rede social Twitter. Assim, propomos análise de textos referentes a um caso particular: o estupro coletivo de uma adolescente no Rio de Janeiro, em 21 de maio de 2016. Causando comoção no país, o caso se tornou conhecido por meio de um vídeo gravado pelos agressores registrando o estupro. São tomadas como corpus postagens de dois ambientes de fala: uma organização da sociedade civil de enfrentamento à violência contra mulheres e dois perfis oficiais do poder público executivo federal. Buscamos analisar como os crimes foram representados; como a jovem agredida foi representada; como a organização não governamental expandiu o debate; se houve mudanças na abordagem do caso ao longo do tempo; como páginas ligadas ao poder público executivo federal responderam à extremada violência e à repercussão social.

Palavras-chave: Discurso; Mulheres; Machismo; Estupro; Redes sociais.

Title: From the video to the complaint: representation of a collective rape posted on Twitter and discursive strategies

Abstract: Based on the theoretical-methodological approach of Critical Discourse Analysis, the article researches discourses regarding violence against women, manifested in the social media Twitter. Thus, we propose analysis of texts referring to a particular case: the collective rape of a teenager girl in Rio de Janeiro, Brazil, on May 21, 2016. Causing commotion in the country, the case became known through a video recorded by the aggressors registering the rape. The corpus is formed by posts collected from two groups: a civil society organization dealing with violence against women and two official profiles of federal executive public power. We sought to analyze how the crimes were represented; how the battered young woman was represented; how the nongovernmental organization expanded the debate; whether there have been changes in the approach of the case over time; how the federal public executive power profiles responded to the extreme violence and social repercussions.

Keywords: Discourse; Women; Patriarchy; Rape; Social media.

\footnotetext{
1 Professora do Departamento de Linguística da Universidade de Brasília. Pesquisadora dos programas de pós-graduação em Linguística e em Desenvolvimento, Sociedade e Cooperação Internacional. Coordenadora do Núcleo de Estudos de Linguagem e Sociedade. Pesquisadora do CNPq. Orcid: https://orcid.org/0000-0002-7791-5757

E-mail: resende.v.melo@gmail.com

2 Jornalista, cursa doutorado em Linguística (Linguagem e Sociedade) na Universidade de Brasília (UnB). É mestre (2019) em Desenvolvimento, Sociedade e Cooperação Internacional pela UnB e especialista em Gestão Pública. Orcid: https://orcid.org/0000-0003-2600-0570

E-mail: nairluisa@gmail.com
} 


\section{Introdução}

Este artigo faz parte de pesquisa mais ampla, baseada na abordagem metodológica de análise interdiscursiva de políticas públicas (AIPP), que propõe investigação acerca de discursos sobre violência contra mulheres, manifestos na rede social Twitter, e sua interface com políticas públicas. O problema social da violência de gênero é considerado objeto para análise de discurso visto que inclui facetas discursivas. Assim, consideramos que os modos como se representam questões de gênero e violência têm influência sobre os modos como a sociedade reage a essas questões, inclusive em termos das propostas de políticas ou ações públicas resultantes de eventos de violência e sua repercussão.

Aqui pretendemos abordar facetas semióticas dessa problemática, portanto propomos análise de textos referentes a um caso particular de violência: o estupro coletivo de uma adolescente no Rio de Janeiro, em 21 de maio de 2016. Para tanto, são tomadas como corpus postagens publicadas no Twitter, ao longo de 45 dias a partir da divulgação do estupro coletivo, a fim de investigar como o caso foi abordado em dois ambientes de fala: uma organização da sociedade civil de enfrentamento à violência contra mulheres (@ThinkOlga) e dois perfis oficiais do poder público executivo federal (@AgoraNoPlanalto e @MichelTemer).

Este artigo está organizado em três seções. Na primeira, contextualizamos o tema específico do estupro coletivo e o macrotema da violência sexual contra mulheres no Brasil. Na segunda seção, abordamos os critérios metodológicos e teóricos que guiaram o estudo. Na terceira, apresentamos nossas análises e, por fim, tecemos considerações finais.

\section{Violência sexual em contexto}

O caso de violência discutido neste artigo se destacou pela crueldade contra a vítima e pelo relevo social que alcançou, causando grande comoção no país.Em 21 de maio de 2016, houve crime de estupro coletivo contra uma jovem, então com 16 anos, no Morro do Barão, no Rio de Janeiro. Um dos agressores gravou e postou no Twitter ${ }^{3}$ um vídeo registrando o estupro. Comentários na postagem sugeriam que mais de 30 homens estariam envolvidos no estupro. Em seguida, o conteúdo foi compartilhado em vários perfis no Twitter e em grupos no Whatsapp ${ }^{4}$. A partir disso, usuárias/os da rede começaram a

\footnotetext{
${ }^{3}$ Twitter é uma rede social em que usuárias/os publicam mensagens de texto, áudio e vídeo na internet. Inicialmente, cada postagem, ou post, (chamada tweet) tinha no máximo 140 caracteres. Desde novembro de 2017, o limite é 280 caracteres.

${ }^{4}$ Whatsapp é um aplicativo multiplataforma de comunicação, desenvolvido para smartphones. Por meio dele é possível fazer ligações e trocar mensagens de texto, arquivos de imagem, áudio e vídeo. Além da comunicação entre dois/duas usuários/as do aplicativo, também é possível criar grupos de conversação com vários/as usuários/as (em que todos/as membros/as recebem e enviam
} 
denunciar o perfil do autor da postagem e o ato registrado nas imagens. A repercussão, portanto, começou nas redes sociais para então alcançar as autoridades. Desta maneira, a adolescente em tela foi alvo de dois crimes: estupro coletivo e gravação e divulgação de imagens do estupro.

Em solidariedade à adolescente, foram organizadas marchas e campanhas de conscientização sobre a cultura de estupro e o machismo. Houve também manifestações de descrédito a respeito da adolescente estuprada e ameaças, inclusive de morte, a ela e à delegada que assumiu o caso.

O governo federal realizou reunião com 27 secretários de Segurança Pública em 31 de maio de 2016, para tratar o tema. O choque da sociedade com o ocorrido chegou a membros do legislativo, que organizaram audiência pública, requisitaram criação de Subcomissão Permanente de Combate ao Estupro e Demais Casos de Violência Sexual contra a Mulher (no âmbito da Comissão Mista de Combate à Violência Contra a Mulher), realizaram pronunciamentos e incluíram o caso na pauta do Projeto de Lei do Senado (PLS) 618/2015, que acrescenta os artigos 218-C e 225-A ao Decreto-Lei no 2.848 , de 7 de dezembro de 1940 (Código Penal), para tipificar crime de divulgação de cena de estupro, e prevê causa de aumento de pena para crime de estupro coletivo.

O 11을 Anuário Brasileiro de Segurança Pública, elaborado pelo Fórum Brasileiro de Segurança Pública (FBSP), aponta que o Brasil registra um estupro a cada 11 minutos. 0 levantamento informa que, em 2016, 49.497 mil pessoas foram estupradas no Brasil. Os números não podem ser percebidos como retrato fiel da realidade, visto que há baixa notificação. Segundo Faúndes et al. (1998), menos de $10 \%$ dos estupros chegam ao conhecimento da polícia.

\section{Percurso teórico e metodológico}

O objetivo deste artigo é estudar a representação discursiva e os modos de ação e interação em textos acerca do caso do estupro coletivo materializados em diferentes ambientes institucionais no Twitter. Mais especificamente, buscamos analisar como os crimes foram representados; como a jovem agredida foi representada; como a organização não governamental (Think Olga), que lida com a temática da violência de gênero, expandiu o debate; ${ }^{5}$ se houve mudanças na abordagem do caso ao longo do tempo; como páginas

mensagens) e listas de transmissão, em que um/a emissor/a envia o mesmo conteúdo para vários/as destinatários/as.

${ }^{5}$ Durante coleta de dados do @ThinkOlga, percebemos que o tema foi expandido ao longo do tempo. Antes da divulgação dos crimes, o perfil dedicava-se a outras temáticas de combate à violência de gênero; depois da divulgação do caso, notamos adoção da pauta. Desta maneira, decidimos observar os efeitos da adoção dessa pauta na promoção do debate sobre o tema na rede social. 
ligadas ao poder público executivo federal (Agora no Planalto e Michel Temer) responderam à extremada violência e à repercussão social.

Para a análise, utilizamos abordagem teórico-metodológica da Análise de Discurso Crítica (ADC). Conforme descreve Blommaert (2005, p. 21), a ADC carrega em si heterogeneidade de abordagem: "Quando falamos de ADC, estamos lidando com um grupo de pesquisadores/as que lideram abordagens, cada qual com seus pressupostos específicos, mas que concordam em certos princípios de análise, que se dirigem a questões similares, e que desenvolveram algumas ferramentas para isso".

Ainda assim, pode-se identificar duas características básicas na ADC: interdisciplinaridade e caráter posicionado. Sobre a primeira característica, Resende (2018, p. 2) a define como "o rompimento de fronteiras disciplinares e o reconhecimento de que para se analisar problemas sociais discursivamente manifestos é preciso operacionalizar conceitos e categorias desenvolvidos pelas Ciências Sociais". O caráter posicionado decorre da adoção de postura explícita da $A D C$ em relação a problemas sociais, não simulando imparcialidade científica (RESENDE, 2008).

O objetivo da ADC é "mapear conexões entre escolhas de atores sociais ou grupos, em textos e eventos discursivos específicos, e questões mais amplas, de cunho social envolvendo poder" (VIEIRA; RESENDE, 2016, p. 26). Desta forma, o propósito da abordagem é expor discursos que servem de suporte a estruturas de dominação ou que limitam a capacidade de transformação dessas estruturas. A ADC pesquisa o discurso como um momento de toda a prática social, entendendo que linguagem sempre figura nas práticas, já que nossas ações são em parte discursivas, e mesmo nosso conhecimento e percepção sobre o mundo não podem ser desvinculados do discurso (CHOULIARAKI; FAIRCLOUGH, 1999).

Para composição do corpus da pesquisa, estabelecemos janela temporal de 45 dias após o acontecimento dos crimes de estupro coletivo e posterior divulgação do vídeo. Desta forma, os posts ${ }^{6}$ coletados foram aqueles publicados entre 21 de maio e 4 de julho de 2016 . Esse período foi suficiente para apontar a evolução do tema específico/ particular (estupro coletivo e divulgação do vídeo) nas redes sociais para a abordagem sobre tema mais abrangente/ genérico (violência contra mulheres). Por esta razão, ressaltamos que a pesquisa de que este artigo é recorte considera os posts publicados sobre o caso específico e aqueles relativos à violência sexual contra mulheres, a partir da divulgação do caso.

A escolha dos perfis do Twitter considerou aqueles que apresentam maior número ${ }^{7}$ de seguidoras/es, dentre perfis integrantes dos dois grupos que escolhemos analisar, com intuito de selecionar aqueles com maior impacto em leitoras/es da rede social.

No mapeamento do número de seguidoras/es dos perfis de organizações da sociedade civil ou sem fins lucrativos no Twitter, dedicadas à luta pelos direitos das

\footnotetext{
${ }^{6}$ Postagem, ou post, aqui corresponde a um tweet, ou seja, uma publicação individual feita no Twitter.

${ }^{7}$ Levantamento feito em 16 de junho de 2017.
} 
mulheres, @ThinkOlga ficou em primeiro lugar, com 103.254 seguidoras/es [quadro (1)].

Quadro 1 - Organizações da sociedade civil em defesa dos direitos das mulheres no Twitter Número de seguidoras/es de organizações da sociedade civil em defesa dos direitos das mulheres no Twitter

\begin{tabular}{|cl|l|}
\hline $1 . \quad$ Think Olga (@ThinkOlga) & 103.254 \\
\hline $2 . \quad$ Marcha das Mulheres (@marchamulheres) & 18.575 \\
\hline $3 . \quad$ Revista AzMina (@revistaazmina) & 5.278 \\
\hline $4 . \quad$ CFEMEA (@cfemea) & 1.447 \\
\hline $5 . \quad$ SOF (@SOFsempreviva) & 518 \\
\hline
\end{tabular}

De forma análoga, comparamos número de seguidoras/es dos perfis oficiais do governo representando presidência da República ou governo federal. Assim, notamos que o perfil Planalto ${ }^{8}$ (canal oficial da presidência da República) estava em primeiro lugar [quadro (2)].

Quadro 2 - Perfis oficiais da presidência da República/ governo federal no Twitter

\begin{tabular}{|cc|l|}
\hline \multicolumn{3}{|c|}{ Número de seguidoras/es de perfis oficiais da presidência da República/ governo federal no Twitter } \\
\hline 1. & Planalto/Agora no Planalto (@planalto/@AgoraNoPlanalto) & 703.269 \\
\hline $2 . \quad$ Agência Brasil (@agenciabrasil) & 115.045 \\
\hline 3. & TV NBR (@TVNBR) & 169.913 \\
\hline $4 . \quad$ Agora Cidadania (@AgoraCidadania) & 17.352 \\
\hline
\end{tabular}

Ademais, escolhemos o perfil de Michel Temer (@MichelTemer - perfil oficial do presidente interino à época do estupro coletivo) não pelo número de seguidoras/es, mas

\footnotetext{
${ }^{8}$ Em 16 de junho de 2017, o perfil do governo federal no Twitter chamava-se Planalto. Até maio daquele ano, quando foi usurpado por hackers, o nome era Agora no Planalto. Por isso pesquisas feitas com perfil @agoranoplanalto não rendem dados. Já a pesquisa com o perfil @ planalto retorna os dados buscados, com o nome antigo do perfil. Desta forma, as postagens analisadas publicadas entre 21 de maio e 4 de junho de 2016 aparecerão como Agora no Planalto.
} 
pela relevância do emissor para o debate. Ainda assim, destacamos que o perfil exibia, à época do levantamento, 785.736 seguidoras/es.

As postagens selecionadas apresentam variedades multimodais: texto, imagens, vídeos, links para outros sites, hashtags e áudios. Esse conteúdo faz parte do corpus da pesquisa mais ampla. Aqui, contudo, nos concentramos nos textos escritos.

Escolhemos o print screen das postagens - e não apenas a transcrição do conteúdo, por exemplo - por ser a forma mais fiel ao conteúdo veiculado nas redes sociais. Acreditamos que os dados analisados tenham funcionamento especial em razão do suporte em que se baseiam. Desta maneira, tudo nelas comunica algo: escolha do léxico, escolha da imagem, presença de links, uso ou não de recursos como emoticons, ${ }^{9}$ uso de caixa alta ou baixa, inclusão de vídeos, GIFs, ${ }^{10}$ legendas, hashtags. ${ }^{11}$ Tudo comunica com leitoras/es familiarizados com as ferramentas disponíveis para esses suportes textuais.

As análises aqui consideram seis categorias discursivas propostas na ADC: estrutura genérica e intertextualidade, do significado acional do discurso; significado de palavras e interdiscursividade, do significado representacional do discurso; modalidade e metáfora, do significado identificacional do discurso.

Fazendo referência a Bakhtin (1997), Vieira e Resende (2016) definem que gêneros implicam atividades específicas ligadas a práticas particulares. Cada atividade social, afirmam, tem seus propósitos específicos ou "escopos intencionais", nas palavras do autor russo. Desta forma, "estrutura genérica corresponde à organização e materialização desses propósitos".

O tweet apresenta especificidades - como limite de textos de até 140 caracteres (à época), além do ambiente de materialização de diferentes modalidades de comunicação. Dessa forma, em razão da diversidade de modos de materialização desse tipo de postagem, consideramos adequado perceber não a realização da categoria discursiva estrutura genérica de cada post, mas, sim, a realização de movimentos retóricos em grupos de posts elencados.

Nesse sentido, o conjunto de posts de cada perfil deve ser compreendido como uma macro-organização textual, de modo que dentro desta organização háváriostipos de estrutura discursiva. Analisamos cada perfil individualmente, de modo que, para cada um, identificamos tipos distintos de ações discursivas que compõem os movimentos retóricos. Destacamos que cada post não realiza apenas uma ação discursiva necessariamente. Em

\footnotetext{
${ }^{9}$ Emoticom é representação gráfica de emoções usando caracteres do teclado.

${ }^{10} \mathrm{GIF}$, do inglês, Graphics Interchange Format ou formato de intercâmbio de gráficos, é formato usado na internet por permitir reprodução de animações de curta duração.

${ }^{11}$ Hashtag, representada pelo símbolo (\#), é mecanismo de indexação de palavras-chave ou termos associados a alguma informação, comumente usada nas redes sociais Twitter, Facebook e Instagram. Seu uso está associado a termos que caem em popularidade ou que alcançam destaque nas publicações das redes sociais, de forma que também é usada para alavancar campanhas, quase como slogans.
} 
alguns, mapeamos ocorrência de três movimentos distintos, por exemplo.

A pluralidade discursiva é característica das postagens do Twitter, de modo que é comum encontrar posts que realizam vários movimentos retóricos e incluem várias vozes. Para explorar esta característica, nos valemos da categoria analítica da intertextualidade. Segundo Fairclough (2001, p. 114), intertextualidade é a propriedade que têm os textos de ser cheios de fragmentos de outros textos. Desta forma, análise da ausência ou presença de vozes particulares permite "explorar práticas discursivas existentes na sociedade e a relação entre elas" (VIEIRA; RESENDE, 2016, p. 135).

$\mathrm{Na}$ interdiscursividade, "a atenção volta-se para os discursos articulados ou não nos textos, bem como as maneiras como são articulados e mesclados com outros discursos" (VIEIRA; RESENDE, 2016, p. 144). As autoras afirmam que frequentemente, pela análise da interdiscursividade, é possível investigar discursos articulados em textos e suas conexões com lutas hegemônicas mais amplas. Por esta razão, a categoria é muito cara à análise desenvolvida aqui, pois permite identificar e analisar os distintos discursos presentes nas postagens e a quais discursos cada perfil se associa. Como já dito anteriormente, esses dados permitem observar a quais discursos hegemônicos se filiam os perfis analisados.

Fairclough (2003) afirma também que a forma como uma pessoa representa o mundo, aquilo com o que ela se compromete é parte de como ela se identifica, necessariamente em relação ao outro com quem interage, isto é, identidades são relacionais: quem uma pessoa é constitui uma questão de como a pessoa se relaciona com o mundo e com outras pessoas. A modalidade é categoria analítica que, de acordo com Halliday (1994), significa o julgamento do falante quanto às probabilidades ou obrigações referentes ao que está sendo dito (Fairclough, 2003, p. 165). Fairclough (2003) comenta que modalidade é importante na estruturação de identidades (tanto nas pessoais personalidades - como nas sociais), no sentido de que aquilo com o que uma pessoa se envolve é parte significativa do que ela é - assim, as escolhas de modalidade nos textos podem ser vistas como parte do processo de estruturação de identidades.

Por fim, também utilizamos a categoria analítica de metáfora. Lakoff (2002) define que "o universo conceitual humano é, por excelência, metafórico". Para Lakoff e Johnson (2000), conceitos metafóricos fornecem compreensão parcial e, por isso, encobrem aspectos dos conceitos que trazem. Assim, estudo das metáforas empregadas nos posts tende a ser revelador sobre preconceitos, tabus, posições ideológicas, machismo e outros conceitos contidos nos textos analisados.

\section{O estupro coletivo no Twitter}

Esta seção se organiza em duas partes: a primeira é dedicada à apresentação da análise discursiva crítica do perfil do Twitter @ThinkOlga; a segunda à análise dos perfis 
ligados à presidência da República: @MichelTemer e @AgoraNoPlanalto. Por fim, apresentamos algumas considerações finais.

Organização da sociedade civil: @ThinkOlga

As postagens de @ThinkOlga foram publicadas no Twitter entre 25 de maio e 30 de junho de 2016. Foram 39 posts, que contêm diferentes tipos de mídia: texto, foto, retuíte ${ }^{12}$, links para sites, uso de hashtags e captura de imagem (screenshot) feita em aparelho móvel.

O conjunto de 39 posts deve ser compreendido como uma macro-organização textual, de modo que dentro desta organização há váriostipos de estrutura discursiva, que, nesta análise, foram identificados como cinco tipos distintos de ações discursivas que comporiam os movimentos retóricos: 1) denúncia, englobando posts de queixa e de cobrança; 2) educativo, incluindo textos que realizam avisos, definem conceitos, comunicam manifestos, resposta, pesquisa direcionada a leitoras/es do @ThinkOlga, anúncio e divulgação de ações e materiais produzidos pela organização da sociedade civil; 3) posicionamento, com expressões de indignação ou insatisfação; 4) mobilização, no sentido de convocar leitoras/es para luta contra a violência dirigida a mulheres; e, finalmente, 5) compartilhamento de outros posts.

Notamos que, dentre essas ações discursivas, há predominância da ação educativa, em 23 ocorrências no corpus. Em seguida, a ação denominada mobilização apresenta-se em 14 ocorrências; a de posicionamento, em dez, e em nove ocorrências cada aparecem denúncia e compartilhamento de outros posts [figura (1)].

Figura 1 - Diagrama de movimentos retóricos nos posts do @ThinkOlga

Movimentos retóricos nos tweets de @ThinkOlga

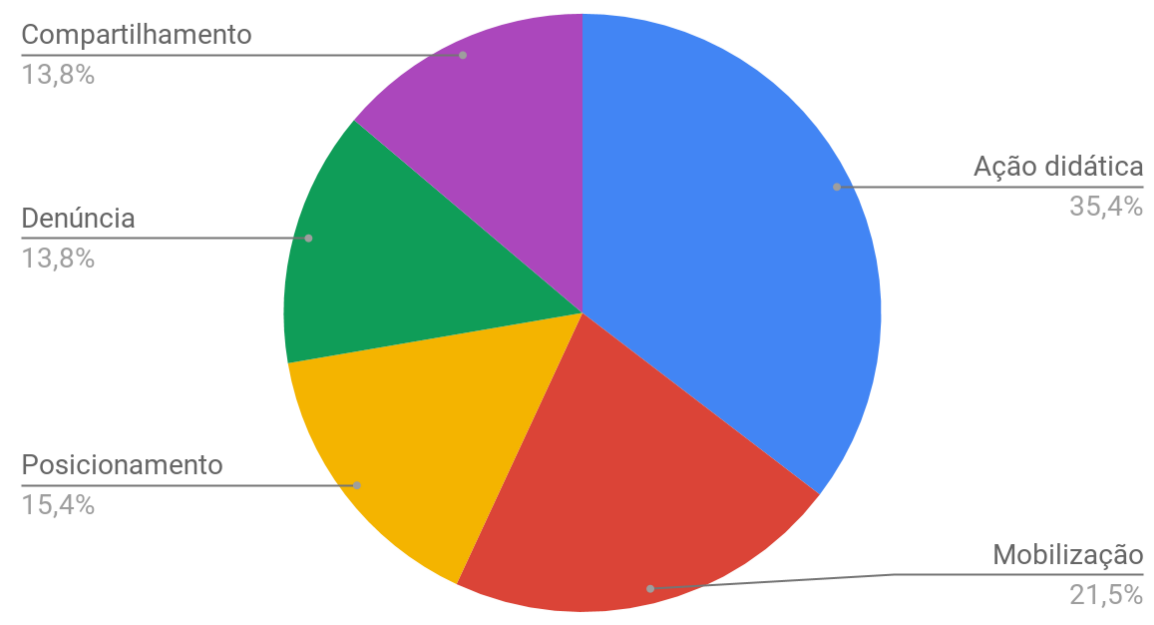

${ }^{12}$ Retuíte é o compartilhamento de outros post feitos no Twitter. 
Cabe ressaltar que cada post não realiza apenas uma ação discursiva necessariamente. No texto (1), por exemplo, há três movimentos distintos:

Figura 2 - Texto (1)

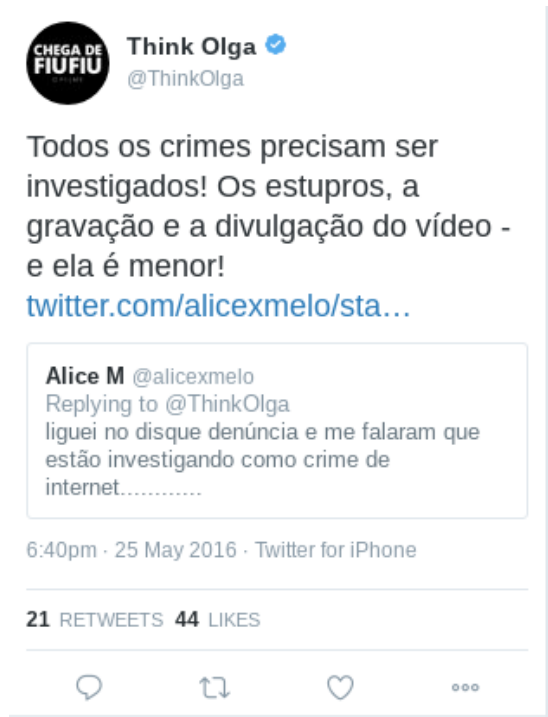

Fonte: printscreen de post do perfil @ThinkOlga no Twitter

No post reproduzido no texto (1), há ocorrência de denúncia ("Todos os crimes precisam ser investigados! Os estupros, a gravação e a divulgação do vídeo"); indignação ("e ela é menor!"); e compartilhamento de outros posts, no caso o do perfil @alicexmelo. 0 perfil compartilhado estende diálogo com a página, estabelecendo resposta no texto "replyingto@ThinkOlga". Reforçando a comunicação realizada pelos movimentos de denúncia e de indignação, o trecho "precisam ser" indica modalidade deôntica alta, de modo que o perfil reforça urgência de ação policial para o crime. Aliam-se a isso, recursos de ênfase na pontuação: o travessão, que confere destaque enfático, e o emprego de pontos de exclamação.

Ao longo dos dias, a presença de mais de um movimento retórico em cada postagem reduz, de forma que passam a apresentar, gradualmente, apenas um movimento. Ademais, percebe-se encadeamento dos movimentos. Apenas no início das postagens - 25 de maio, quatro dias depois do estupro - predominam nos posts denúncia e compartilhamento de outros posts. No dia seguinte, 26 , há predominância da ação de posicionamento. Já no terceiro dia consecutivo de postagens relativas ao tema, 27, nota-se predominância da ação educativa. No quarto dia, 28, volta-se para predominância de posicionamento. Apenas dois dias depois, 30, há novas postagens sobre o tema, desta vez realizando anúncio, ou seja, ação educativa. No dia seguinte, 10 de junho, nota-se mobilização. No dia 3, ação educativa; no dia 4, posicionamento, novamente. De 6 de junho em diante, até dia 30, ocorre 
predominância da ação educativa [quadro (3)].

Quadro 3 - Evolução cronológica dos movimentos retóricos predominantes

\begin{tabular}{|r|r|l|l|l|}
\hline & $\begin{array}{c}\text { Denúncia/ } \\
\text { Compartilhamento }\end{array}$ & Posicionamento & Ação educativa & Mobilização \\
\hline $25 / 05$ & & & & \\
\hline $26 / 05$ & & & & \\
\hline $27 / 05$ & & & & \\
\hline $28 / 05$ & & & & \\
\hline $30 / 05$ & & & & \\
\hline $01 / 06$ & & & & \\
\hline $03 / 06$ & & & & \\
\hline $04 / 06$ & & & & \\
\hline 06 a $30 / 06$ & & & & \\
\hline
\end{tabular}

Esse encadeamento das ações mostra ritmo, ou evolução, do modo como o crime de estupro coletivo articula-se textualmente nesse perfil. Inicialmente, a denúncia do crime é a ação motivadora das postagens, seguida pela indignação que gera no @ThinkOlga. A partir desses dois momentos (denúncia-indignação), percebe-se movimento de mobilização (marcha de resistência à violência contra mulheres) e lançamento de materiais desenvolvidos pelo grupo sobre o tema; nestes há, sobretudo, ação educativa. Isso nos leva a pensar que a partir do momento em que o perfil passa a divulgar o crime de estupro e a existência do vídeo que registra o estupro - a ação concreta na sociedade -, o que ocorre em seguida é um momento de reflexão sobre a violência sofrida pela adolescente, expressa pelo posicionamento/ indignação/ mobilização. Em seguida, o grupo age de forma decidida, por meio de predominância total nas postagens da ação educativa, no sentido de educar e informar leitoras/es sobre violência de gênero e machismo. Portanto, parte-se do caso concreto, individual (estupro coletivo) para pauta ampla e abstrata (fim do machismo e da violência contra mulheres na sociedade brasileira).

Interessante apontar outro encadeamento. Desta vez, entre as vozes articuladas nos posts e os movimentos retóricos. Há três formas de intertextualidade nos posts: citação direta (seja de outros posts, seja inserida no texto como discurso direto); citação de site (com link para acessar conteúdo externo ao @ThinkOlga) e vocativo. Destaca-se que a voz 
Do vídeo à denúncia: representação do estupro coletivo no Twitter e estratégias discursivas

da adolescente agredida inclui-se na citação direta "apudeada"13 e aparece apenas duas vezes ao longo dos 39 posts:

Figura 3 - Texto (2)

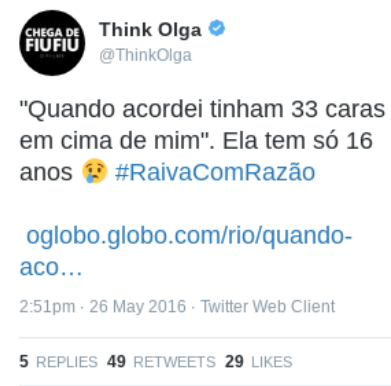

Fonte: printscreen de post do perfil @ThinkOlga no Twitter

Figura 4 - Texto (3)

FiUGA

Think Olga $\odot$

@Thinkolga

\#RaivaComRazão

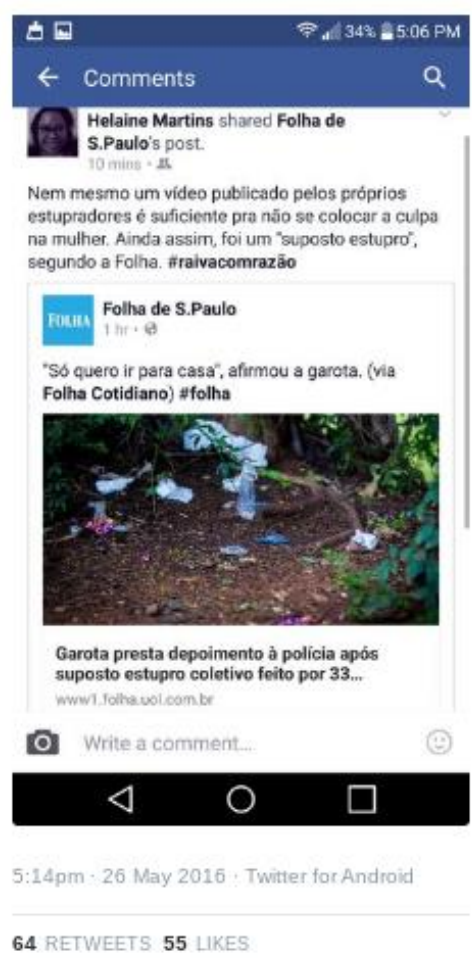

Fonte: printscreen de post do perfil @ThinkOlga no Twitter

\footnotetext{
${ }^{13}$ Ou seja, citação direta reproduzida de outro texto, em estrutura de apud.
} 
Nos dois casos, são citações diretas do depoimento à polícia, recuperadas por veículos de comunicação e depois apudedadas no perfil em análise. A opção por manter as aspas em citação direta tem o efeito retórico de aproximar a voz da adolescente do perfil que contempla essa relação intertextual. As aparições da voz da adolescente se dão no dia 26, aquele em que há predominância do movimento retórico de posicionamento/ indignação. Por essa razão, é possível sustentar que a voz da jovem serve como elemento que contribui para criação de choque em decorrência da violência, e, por conseguinte, comunicação de indignação.

O texto (2) estabelece relação de paralelismo com o texto (1): o que antes era "e ela é menor!", agora aparece como "ela só tem 16 anos". Nos dois posts, ocorre recurso de ênfase na pausa da pontuação e em zona focal no fim do post, para intensificar o impacto pretendido. Ademais, no texto (2) o emprego do emoticom contribui para reforçar o efeito enfático pretendido. Entre os textos (2) e (3), a coesão se dá pelo emprego repetido da hashtag \#RaivaComRazão, padrão que se repetirá em outras postagens.

No primeiro dia de postagem, 25 de maio, o movimento predominante é de denúncia e, nele, há materialização de outras vozes por meio de citação direta, especialmente de outros perfis do Twitter. Voltando à ação educativa - que se manifestou de forma majoritária nos 39 posts -, ela se dá junto com os três tipos de intertextualidade mapeados no corpus. Há, contudo, predominância de citação de sites nesta situação. Isso leva a concluir que, para @ThinkOlga realizar o intento educador e conscientizador de leitoras/es, há necessidade de extrapolar o ambiente sucinto dos 140 caracteres do Twitter. Assim, o Twitter não é usado diretamente como plataforma para a ação educativa, mas como suporte para articulação intertextual, pois leva a outro espaço na internet mais apropriado a essa ação discursiva. Tanto a pauta levantada pela organização de modo macro (defesa dos direitos de mulheres), quanto aquela apresentada de modo específico ao caso estudado (fim do machismo e da violência contra mulheres) não cabem no Twitter. O debate precisa ser aprofundado, exigindo acesso a sites externos à rede social, ou seja, maior espaço de produção discursiva. A rede social funciona nesses casos como um chamariz.

Considerando que o grande intento das postagens é educar/ conscientizar, pode-se dizer que o Twitter serve como anzol, para fisgar leitoras/es, com intuito não de tirar-lhes do mar (para manter metáfora da pesca), mas para convidar para mergulho em águas mais profundas, as do debate da questão da violência contra mulheres na sociedade brasileira. Desta forma, acreditamos ser possível dizer que @ThinkOlga faz apropriação criativa do suporte Twitter e transgride sua proposta de brevidade comunicativa, chamando leitoras/es para outros ambientes na internet fora da rede social.

Com isso em mente, seguimos para a próxima categoria analítica: interdiscursividade. A discussão é baseada em cinco exemplos [textos (4) a (8)], a seguir: 
Do vídeo à denúncia: representação do estupro coletivo no Twitter e estratégias discursivas

Figura 5 - Texto (4)

CHEAFAO Think Olga

@ThinkOlga

"Fazer de cada lágrima que se sucedeu um justo motivo para as nossas lutas!"

marchamulheres.wordpress.com/20

16/05/25/faz... \#RaivaComRazão

1:43pm · 26 May 2016 · Twitter Web Client

1 REPLY 25 RETWEETS 30 LIKES

Fonte: printscreen de post do perfil @ThinkOlga no Twitter

Figura 6 - Texto (5)

CHEGAD Think Olga $\odot$ @ThinkOlga

"Pq não reagiu?", "Pq foi a 1 festa depois?", "Pq não gritou?" etc são argumentos utilizados para colocar vítimas em xeque - Isso é MACHISMO

7:18pm · 3 Jun 2016 - Twitter Web Client

27 RETWEETS 60 LIKES

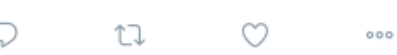

Fonte: printscreen de post do perfil @ThinkOlga no Twitter

Figura 7 - Texto (6)

CHEGADE

Think Olga $\theta$

@Thinkolga

No RJ, 63\% dos agressores não têm condenação ou punição em ações por estupro de vulnerável extra.globo.com/noticias/rio/e... extra.globo.com/noticias/rio/e...

9:18am - 6 Jun 2016 - Twitter Web Client

37 RETWEETS 28 LIKES

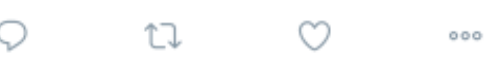

Fonte: printscreen de post do perfil @ThinkOlga no Twitter 
Figura 8-Texto (7)

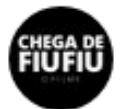

Think Olga $\theta$

@ThinkOlga

\section{Organizações se unem p/ \\ pressionar a aprovação de PL \\ inédito à garantia dos direitos de \\ crianças e adolescentes \\ bit.ly/28JDyz3}

5:10pm $\cdot 20$ Jun 2016 · Twitter Web Client

○Rio de Janeiro, Brazil, Brazil

4 RETWEETS 5 LIKES

๑ $\bigcirc$

Fonte: printscreen de post do perfil @ThinkOlga no Twitter

Figura 9 - Texto (8)

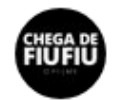

Think Olga

@ThinkOlga

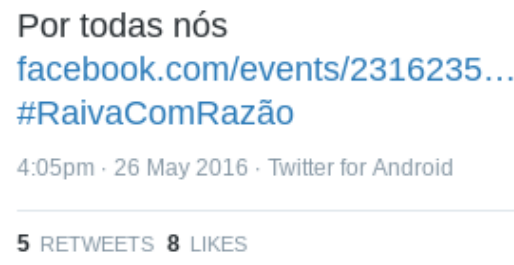

Fonte: printscreen de post do perfil @ThinkOlga no Twitter

Em 28 posts do corpus, identificamos presença de discurso feminista [por exemplo, nos textos (4) e (5)], aparição coerente com a identidade da organização. No texto (4), a frase "Fazer de cada lágrima que se sucedeu um justo motivo para as nossas lutas!" convoca mulheres para se unirem - em solidariedade às mulheres que sofreram e sofrem violência oriunda do machismo na sociedade - para lutar por uma sociedade mais justa com as mulheres.

Mais uma vez, o elemento de coesão entre os posts é a hashtag \#RaivaComRazão, presente nos textos (2), (3), (4) e (8). Ademais, no texto (4), análise aponta modalidade deôntica na frase com verbo no infinitivo "fazer", dado que se infere a existência de um "é preciso", comunicando uma ação necessária para o problema da violência contra mulheres segundo @ThingOlga.

Há no texto (5) relação intertextual com ditos tomados como genéricos 
(intertextualidade com enunciador genérico). $O$ caráter genérico também se expressa no "etc", que indica um elenco de possíveis enumerações de possíveis falas descritas no post como "argumentos para colocar vítimas em xeque". Mais uma vez, há recurso de ênfase na zona focal no fim do texto, como estratégia de reforçar o argumento de @ThinkOlga, desta vez, materializado pelo uso do termo machismo, grafado em caixa alta.

Em segundo lugar, em 16 posts, mapeamos discurso contra violência presente, por exemplo, no texto (6), em que se lê chamada do jornal Extra (indicada pela inclusão de link para a matéria): "No RJ, 63\% dos agressores não têm condenação ou punição em ações por estupro de vulnerável". O dado mencionado, 63\% não são punidos, se relaciona com a manutenção do estado das coisas, ou seja, uma sociedade que é conivente com a violência sexual - nesse texto específico, contra vulneráveis.

Há também 13 materializações de discurso de direito legal [por exemplo, texto (7)], em compasso com o movimento retórico predominante: ação educativa. O texto (7) exemplifica uma das pautas do grupo Think Olga, de advogar por sociedade mais justa com mulheres. Nele, lê-se a chamada "Organizações se unem $p /$ pressionar a aprovação de PL inédito à garantia dos direitos de crianças e adolescentes" seguida do link para o site GIFE, do Grupo de Institutos Fundações e Empresas. O texto indica que uma das formas de se alcançar o intento de @ThinkOlga (de promover a garantia de direitos sociais) é pela via legislativa.

Percebe-se, também, incidência, mais baixa contudo, de discurso de engajamento [texto (8)]. Nele, está escrito: "Por todas nós", seguido de link para um evento organizado no Facebook chamado Por TODAS ELAS, que se realizaria em 1 de junho de 2016, em São Paulo. Há também na postagem a hashtag "\#RaivaComRazão", usada em boa parte dos posts de 26 de maio, de modo que comunicam unicidade às postagens do dia e também reafirmam o mote que estimula as ações do @ThinkOlga, que ocorrem em reação à violência sofrida pela adolescente agredida. Como discutido anteriormente, as aparições da voz da adolescente estuprada se dão apenas em 26 de maio, de forma que uso da hashtag reforça movimento retórico predominante no dia: posicionamento/ indignação.

Acerca da ação educativa, destaca-se que o discurso de direito legal aparece, predominantemente, nas postagens que realizam ação de educação/ mobilização: das 13 incidências, dez estão relacionadas com a ação educativa e passam a surgir no corpus com mais intensidade a partir de 1 de junho. Isso nos leva a pensar que a organização elabora o propósito de educar para erradicar machismo e violência contra mulheres sob perspectiva legal, jurídica [quadro 4]. 
Quadro 4 - Evolução cronológica dos movimentos retóricos predominantes $\mathrm{x}$ discurso de direito legal

\begin{tabular}{|c|c|c|c|c|}
\hline & Denúncia/ Compartilhamento & Posicionamento & Ação educativa & Mobilização \\
\hline $25 / 05$ & $\begin{array}{c}\text { Discurso de direito legal } \\
\text { (1 ocorrência) }\end{array}$ & & & \\
\hline $26 / 05$ & & & & \\
\hline $27 / 05$ & & & & \\
\hline $28 / 05$ & & & & \\
\hline $30 / 05$ & & & $\begin{array}{c}\text { Discurso } \\
\text { de direito legal } \\
\text { (2 ocorrências) }\end{array}$ & \\
\hline $01 / 06$ & & & & $\begin{array}{c}\text { Discurso } \\
\text { de direito legal } \\
\text { (3 ocorrências) }\end{array}$ \\
\hline $03 / 06$ & & & $\begin{array}{c}\text { Discurso } \\
\text { de direito legal } \\
\text { (3 ocorrências) }\end{array}$ & \\
\hline $04 / 06$ & & & & \\
\hline 06 a $30 / 06$ & & & $\begin{array}{c}\text { Discurso } \\
\text { de direito legal } \\
\text { (4 ocorrências) }\end{array}$ & \\
\hline
\end{tabular}

O quadro 4 une informações do quadro 3, que mostra encadeamento dos movimentos retóricos ao longo da série de posts, à listagem dos dias em que há discurso legal de direito. Dada prevalência de ação educativa nos posts, o quadro (4) evidencia que discurso de direito legal está presente quando há intuito educativo. Desta forma, identificamos um traço da construção argumentativa do @ThinkOlga acerca da violência contra mulheres: o problema está no campo dos direitos civis, na falência da sociedade brasileira em garantir esses direitos.

Ainda sobre a ação educativa, a análise do léxico utilizado nos posts mostra recorrência de termos: "estupro" (15), "assédio" (5), "assédio sexual” (5), "abuso sexual" (4). Nota-se variação nos termos que definem distintos tipos de crimes sexuais, de modo que é possível perceber gradação de abrangência, partindo de um crime mais específico (estupro) para termos que comunicam maiores possibilidades de significado (assédio e abuso). Essa 
gradação é observada na cronologia dos posts: entre 25 de maio e 1 de junho, há 13 incidências do termo "estupro" e variações. A partir disso, surgem outros termos como "violência sexual" e "assédio". Nota-se, em consonância com a ação educativa, extrapolação do tema iniciador do debate (estupro coletivo), para ampliação do tema, de modo abstrato. A mudança lexical, a gradação de abrangência, partindo de uma violência mais específica (estupro) para uma menos específica, contudo mais ampla de sentido (assédio ou abuso), indica mudança de abordagem: do problema concreto individual para problema abstrato, coletivo, das mulheres brasileiras.

A passagem concreto/ particular para abstrato/ geral fica marcada no post de 27 de maio [texto (9)]:

Figura $10-$ Texto (9)

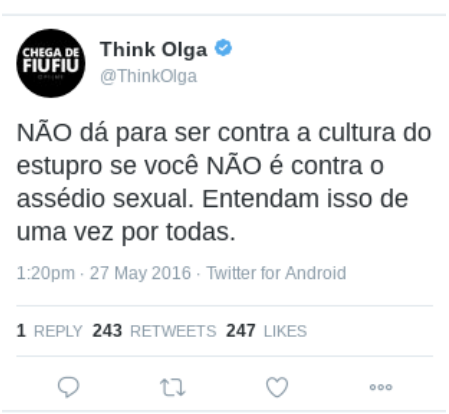

Fonte: printscreen de post do perfil @ThinkOlga no Twitter

Também no texto (9) destaca-se ocorrência de modalidade deôntica de obrigatoriedade ("NÃO dá" e "Entendam"). Na primeira frase, marcada pela polaridade negativa, os dois termos "não" ocorrem em caixa alta, em abordagem que reforça posicionamento do @ThinkOlga. De forma análoga a posts anteriores, há pausa enfática em zona focal do texto ("Entendam isso de uma vez por todas"), evidenciando padrão na estratégia comunicativa do perfil.

Por fim, encontramos algumas recorrências no uso de metáforas no corpus. Nos posts que realizam movimento retórico de mobilização, é recorrente uso de metáforas ontológicas, tanto no sentido de expressar que o enfrentamento da violência contra mulheres é luta ("Mulheres em luta"/ "Marchamos juntas") quanto no sentido de convocar uma unidade muito além de pessoas em prol da causa, mas a conformação de um corpo, uníssono, de mulheres que se solidarizam com sofrimento das outras [texto (10) a seguir]. A unidade é evocada pela metáfora "Mexeu com uma, mexeu com todas", que descreve as mulheres como organização una, sensível às dores umas das outras, em pleno exercício de sororidade. 
Figura $11-$ Texto (10)

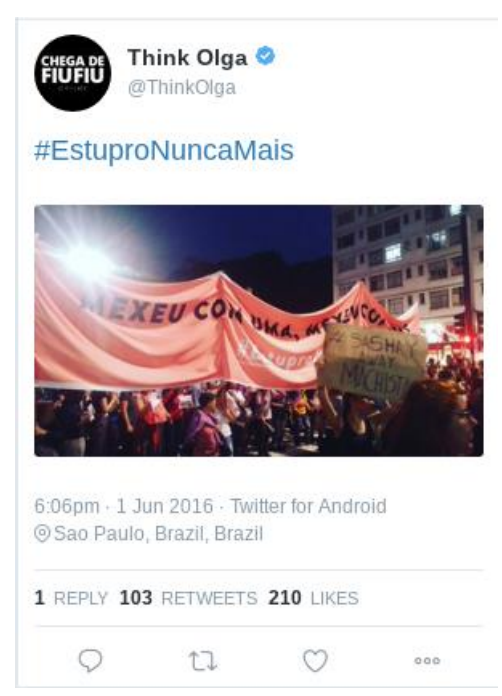

Fonte: printscreen de post do perfil @ThinkOlga no Twitter

No texto (10), vê-se no post foto da marcha de protesto que aconteceu em São Paulo, em 1ำ de junho de 2016. Nele, há faixa carregada por manifestantes, em que se lê "Mexeu com uma, mexeu com todas". É a partir dessa data que o termo estupro (concreto/ particular) diminui drasticamente de incidência nas postagens. Deste dia em diante, a violência passa a ser referida como assédio ou abuso (abstrato/ geral). Mais uma vez, identifica-se extrapolação da pauta do @ThinkOlga: de denúncia de caso singular, passa-se a oportunidade para levantar bandeira em prol de uma luta de todas ("mexeu com todas") as mulheres que sofrem violência de gênero.

A análise permite concluir que @ThinkOlga escolhe não fazer da adolescente agredida um exemplo para militância dos direitos das mulheres. Tampouco explora e expõe exageradamente o sofrimento da adolescente. Os crimes suscitam indignação e levante contra a violência dirigida a mulheres no Brasil. Isso ocorre por meio da passagem do tema concreto/particular para o tema abstrato/geral. E vai além, pois mobiliza ações do @ThinkOlga no sentido de conscientizar leitoras/es sobre machismo e violência de gênero. Desta forma, pode-se entender que o perfil aproveita a brevidade da plataforma Twitter para lançar iscas a leitoras/es, no sentido de atraí-las/os para outros textos, mais amplos, fora da rede social. E faz mais: convoca para mobilização e manifestação nas ruas.

Poder Público: @MichelTemer e @AgoraNoPlanalto

Aqui o foco desloca-se para as manifestações no Twitter de dois perfis oficiais do poder público: o do presidente interino à época dos crimes, Michel Temer (@MichelTemer), e o do perfil oficial do gabinete da presidência da República, @AgoraNoPlanalto. 
O perfil @MichelTemer publicou sobre o caso do estupro coletivo em dois dias: 27 de maio (oito tweets) e 31 de maio (dois tweets). Os posts do dia 27 compõem nota oficial, publicada no site da presidência da República, apesar de isso não ser explicitado no perfil. De forma a adaptar a nota ao limite de 140 caracteres do Twitter, o texto foi dividido em oito posts. A estratégia é evidenciada pelo encadeamento das ideias, pela sequência das postagens no tempo - a primeira postagem ocorre às $11 \mathrm{~h} 33$ e a última às $11 \mathrm{~h} 36$-, pelo recurso das reticências de continuidade e pelo nexo intertextual "replyingto @MichelTemer" (em resposta à @MichelTemer).

Destacamos a pouca exploração do recurso da multimodalidade, oferecido pelo Twitter, por parte de @MichelTemer. Inexiste inserção de imagens, vídeos ou áudios. Os tweets são exclusivamente compostos por textos verbais e realizam padrão de comunicação institucional governamental.

É interessante observar os movimentos retóricos existentes nas postagens. Identificamos quatro movimentos retóricos distintos nas dez postagens: 1) repúdio, incluindo postagem de indignação; 2) prestação de contas, ou seja, resposta do governo à população acerca do caso; 3) promessa e 4) anúncio da agenda do então presidente interino.

As postagens do dia 27 apresentam evolução interna sobre o tema. Primeiramente, expressam indignação de @MichelTemer sobre o estupro [texto (11)], depois, partem para prestação de contas sobre o que já foi feito pelo governo [texto (12)]. Em seguida, tomam lugar as promessas de governo para sanar a violência contra mulheres [texto (13)] e, depois, o tema inicial (estupro coletivo) é retomado, e o perfil volta ao que nomeamos como prestação de contas, afirmando que haverá ação para "apurar as responsabilidades e punir com rigor os autores do estupro e das divulgação do ato criminoso nas redes sociais" [textos (14) e (15)]. A seguir, os textos (11) a (15).

Figura 12 - Texto (11)

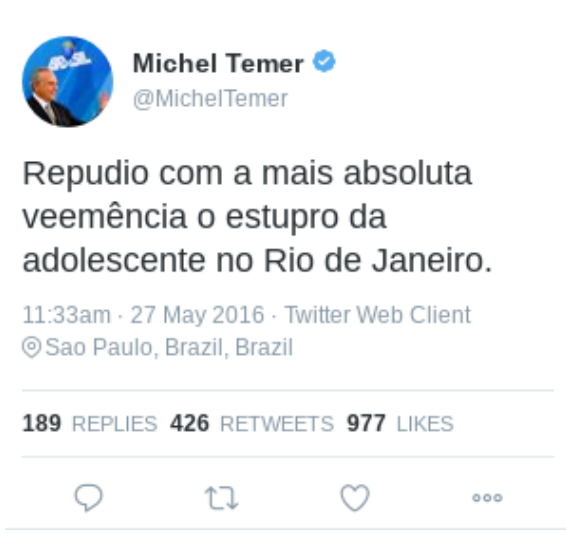

Fonte: printscreen de post do perfil @MichelTemer no Twitter 
Figura 13 - Texto (12)

Michel Temer

$@$ MichelTemer

Replying to @MichelTemer

O ministro da Justiça convocou

reunião com os secretários de segurança pública de todo país, nesta terça-feira.

11:34am - 27 May 2016 - Twitter Web Client

๑Sao Paulo, Brazil, Brazil

31 REPLIES 164 RETWEETS 362 LIKES

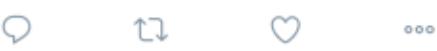

Fonte: printscreen de post do perfil @MichelTemer no Twitter

Figura 14 -Texto (13)

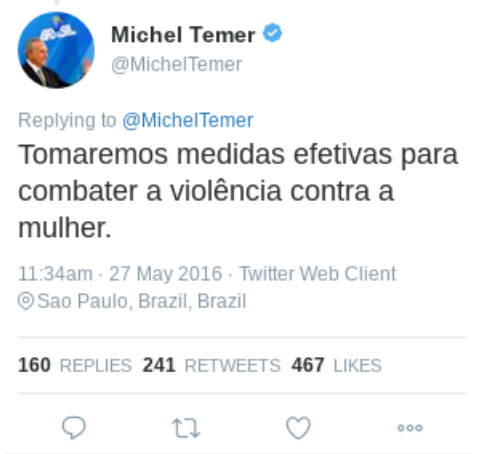

Fonte: printscreen de post do perfil @MichelTemer no Twitter

Figura $15-$ Texto (14)

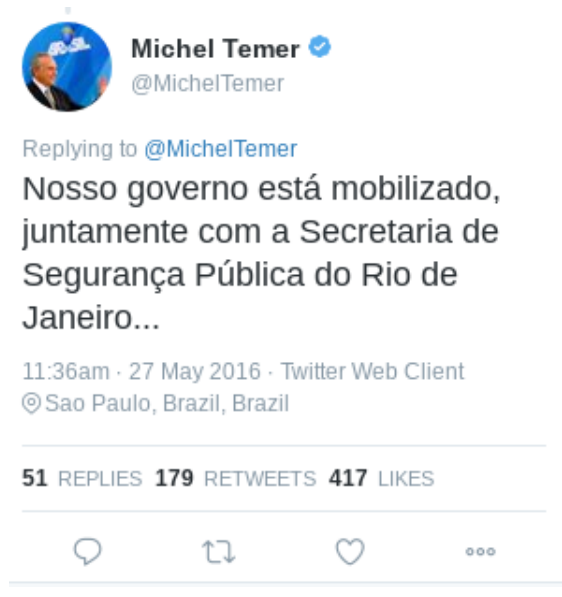

Fonte: printscreen de post do perfil @MichelTemer no Twitter 
Figura 16 - Texto (15)

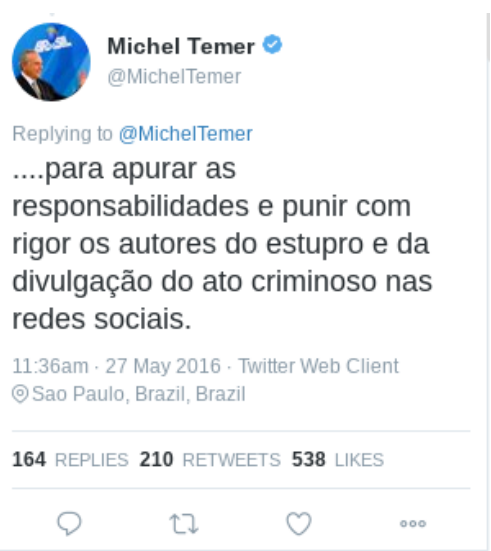

Fonte: printscreen de post do perfil @MichelTemer no Twitter

O conjunto desses posts realiza pronunciamento padrão de entes governamentais. $\mathrm{O}$ perfil inicia diálogo com público fazendo referência ao tema que tomou a sociedade (estupro coletivo). Daí, aproveita a oportunidade para mencionar ações pregressas e futuras da gestão - ou seja, para ampliar o debate, partindo do caso particular do estupro e abordando tema mais amplo - violência contra mulheres -, e, por fim, volta ao tema inicial e responde ao que @MichelTemer indica ser o anseio da sociedade: punição rigorosa dos agressores.

Ao longo dos posts, há predominância dos movimentos retóricos de prestação de contas e de promessas, com três ocorrências de cada. Assim, $60 \%$ dos textos sobre o caso fazem menção a ações governamentais. Não é de surpreender que a palavra mais recorrente nos textos seja "segurança". Mas não qualquer: os posts mencionam quatro vezes o termo "segurança pública". Disso, podemos compreender que tanto o caso específico (estupro coletivo) quanto o tema amplo (violência contra mulheres) são percebidos pelo perfil como questões de segurança pública. Assim, o perfil toma o caso como suporte para ênfase no tema mais amplo da segurança pública, respondendo ao caso em termos de punição rigorosa [texto (15)].

Cabe notar que nos dois posts que realizam "repúdio" há modalidade epistêmica alta e subjetiva, com esforço de avaliação marcado pelo termo "a mais absoluta veemência" [texto (11)]. A estrutura modal dialoga com o intuito do post de comunicar extrema reprovação ao crime cometido. Além disso, a escolha do léxico "Repudio" dialoga com a necessidade de reforçar o argumento do emissor, de forma que a frase cai em redundância: repudiar significa condenar ou repelir e, assim, os advérbios ocorrem como ferramenta de impacto. O peso da argumentação centrada no léxico também é observado no texto (13), dada inexistência de argumentos explícitos: "medidas efetivas" são palavras vazias de sentido específico. Apesar disso, são palavras que carregam em si peso argumentativo, reforçando a observação da argumentação com base na linguagem.

Assim como foi percebido em @ThinkOlga, há pouca menção à jovem agredida. Aqui, há apenas uma: "estupro da adolescente no Rio de Janeiro" [texto (11)], presente no 
primeiro post da série de tweets. A menção ao termo "mulher", e suas variações, ocorre três vezes. Em duas delas, "mulher" vem acompanhada do termo "violência", como em "violência contra a mulher". A terceira ocorrência se dá no seguinte tweet [texto (16)]:

Figura 17 - Texto (16)

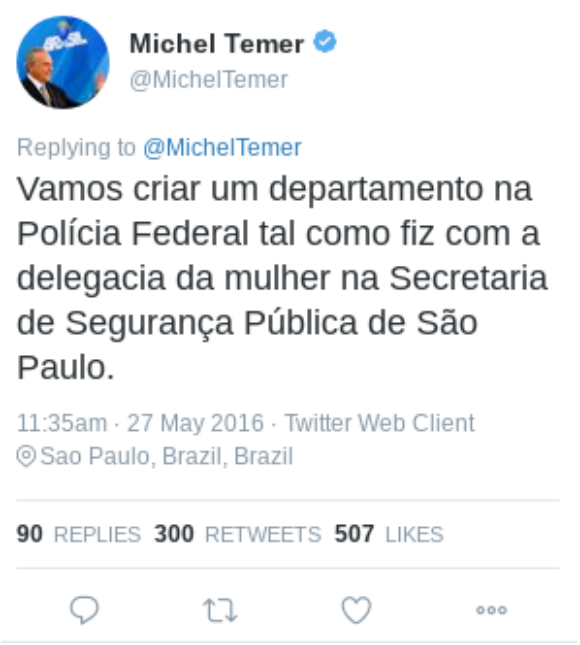

Fonte: printscreen de post do perfil @MichelTemer no Twitter

Considerando essas ocorrências, é possível dizer que a representação das mulheres nessas postagens corresponde a um ser passivo (no sentido de não ser representada como agente de qualquer ação, mas como beneficiária de ações de outros).

A flutuação na autorreferência pela primeira pessoa, ora do singular, ora do plural, e a oposição 'nós versus eles' são interessantes nesses tweets. Como as primeiras oito postagens (de 27 de maio) correspondem a uma nota oficial, percebe-se ocorrência de primeira pessoa, tanto singular quanto plural. O primeiro tweet já indica a tendência: "Repudio com a mais absoluta veemência...". A segunda ocorrência de primeira pessoa no singular pode ser lida no texto (16). Nele, @MichelTemer destaca ação pregressa do presidente interino Michel Temer: criação da delegacia da mulher, em São Paulo.

Nas postagens, existem quatro usos da primeira pessoa no plural: "tenhamos que conviver com crimes bárbaros"; "tomaremos medidas", "vamos criar" e "nosso governo". Destes, apenas o primeiro refere-se à toda sociedade, sendo um "nós" inclusivo. Os outros três referem-se ao governo interino e evocam união entre ações estaduais e federais, sendo, portanto "nós" exclusivos.

Cabe destacar o momento histórico em que aconteceram os crimes em tela. Dias antes, em 12 de maio, a presidenta eleita Dilma Rousseff foi afastada do cargo por prazo de 180 dias, em razão da instauração de processo de impeachment contra ela. Nesse período, o vice-presidente, Michel Temer, assumiu como interino. Considerar a conjuntura política fornece subsídios para compreender a cadeia de postagens. Primeiro, dada a instabilidade 
política e a falta de aceitação do governo interino, acreditamos que a necessidade do perfil @MicherTemer em endereçar o caso do estupro que gerou comoção nacional configura tentativa de alcançar alguma legitimidade nos corações e mentes de brasileiras/os. Segundo, as reiteradas menções ao governo e sua unidade podem ser percebidas como esforço para afirmar suposta solidez da estrutura governamental.

As postagens de 31 de maio ajudam a perceber isso. Os dois tweets já não ocorrem em primeira pessoa. No início dos dois, há uma indicação "(Al)" de que quem fala não é Temer, mas a assessoria de imprensa presidencial. Ademais, nas duas postagens, que realizam o movimento retórico do "anúncio", a menção a Temer é "presidente Michel Temer", um reforço de posição, de funcionalização, que dialoga com o momento de instabilidade política e se configura como mais um esforço de legitimação do então presidente interino.

Quanto ao tema da oposição 'nós versus eles', destacamos que há três grupos referidos como terceira pessoa: os agentes do Estado - e que, no fim, também compõem o 'nós' (governo); 'a mulher' (entidade abstrata); e os autores dos crimes. Nesse escopo, duas das ocorrências do termo "mulher" surgem nos mesmos posts em que há primeira pessoa do plural: "Tomaremos medidas efetivas para combater a violência contra a mulher"; "Vamos criar um departamento na Polícia Federal tal como fiz com a delegacia da mulher na Secretaria de Segurança Pública". Nesses dois casos, observa-se agência atribuída ao "nós" em oposição ao papel de beneficiária atribuído a "mulher". A terceira ocorre em 31 de maio. Desta vez, as postagens são da assessoria de imprensa, conforme reprodução a seguir do texto (17):

Figura $18-$ Texto (17)

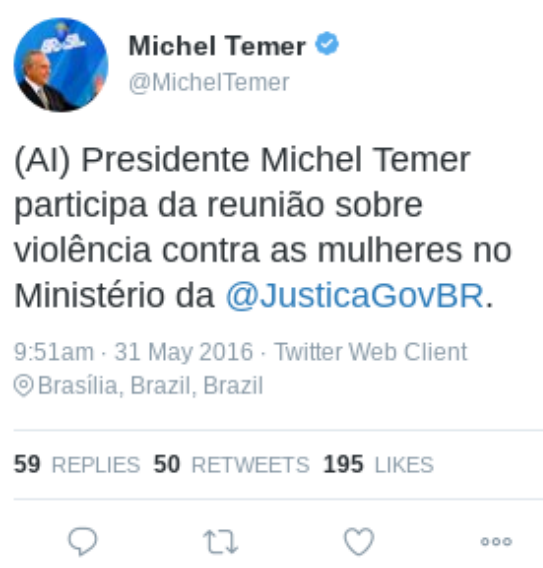

Fonte: printscreen de post do perfil @MichelTemer no Twitter

Considerando essas ocorrências, notamos existência de segunda dinâmica 'nós versus eles'. No caso, nós (governo, composto por homens, agentes das ações) versus elas (mulheres). Para exemplificar, há a sequência de posts "O ministro da Justiça convocou 
reunião com os secretários de segurança pública de todo país, nesta terça-feira" e "Tomaremos medidas efetivas para combater a violência contra a mulher". Nós, aqui, é o governo, composto por Michel Temer, pelo ministro da Justiça e os secretários de segurança pública. A escolha do plural genérico masculino em "os secretários de segurança pública" é entendida não só como escolha ideológica como também correspondente à realidade do governo interino à época, formado exclusivamente por homens brancos, e posteriormente, duramente criticado por isso.

Em dois tweets, há marcação de interdiscursividade [textos (13) e (15)]. No post reproduzido no texto (13) - que realiza movimento retórico de promessa -, há discurso legal e bélico. Nele, lê-se: "Tomaremos medidas efetivas para combater a violência contra a mulher". A escolha do termo "combater" indica adoção de discurso bélico, visto que para @MichelTemer, violência contra mulheres é inimiga e, portanto, precisa ser combatida. Além disso, a construção "tomaremos medidas efetivas" faz referência às instâncias legais e judiciais, as quais devem ser as responsáveis por combater a inimiga (violência), ou seja, filiase a discurso de direito. No post presente no texto (15) - que realiza movimento de prestação de contas -, há discurso punitivo. Nele, lê-se: "para apurar as responsabilidades e punir com rigor os autores do estupro e da divulgação do ato criminoso nas redes sociais", em que o discurso punitivo está materializado pela escolha da construção "punir com rigor". Este post corresponde à parte final da nota oficial e, como dito, é aquele em que o governo se ocupa em responder à sociedade, prometendo punição rigorosa aos criminosos.

Das metáforas existentes, a que pode ser observada do post reproduzido no texto (14), "Nosso governo está mobilizado", estabelece diálogo com o que já mencionamos. A metáfora personifica o governo de Temer e indica que o governo está envolvido em ação coesa. A escolha da metáfora reforça a unidade governamental e indica que haveria preocupação conjunta em identificar os criminosos e puni-los. Em outras palavras, o governo interino se autorrepresenta como sólido, atento ao clamor da sociedade e agindo com justiça e prontidão.

Em consonância com @MichelTemer, o perfil oficial da presidência da República @AgoraNoPlanalto também publicou sobre o caso do estupro coletivo, e também em 27 e 31 de maio. No total foram nove tweets sobre o tema.

Figura $19-$ Texto (18) 
Agora No Planalto 0

@AgoraNoPlanalt

\#NotaOficial de @MichelTemer:

repúdio veemente ao estupro de

adolescente no Rio bit.ly/25mu89t

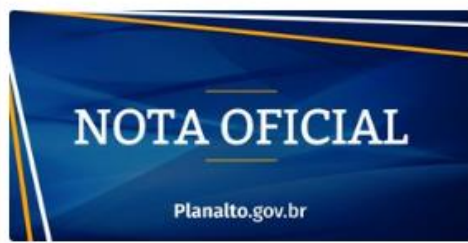

1.19pm · 27 May 2016 · Twitter Web Client

24 REPLIES 27 RETWEETS 81 LIKES

Fonte: printscreen de post do perfil @AgoraNoPlanalto no Twitter

Há dois movimentos retóricos nos posts desse perfil: comunicado oficial e fala governamental. O último é o que apresenta maior recorrência (5). A aparição dos movimentos se dá de forma intercalada: os posts iniciam com comunicado, depois passam para fala governamental e voltam para comunicado, e assim seguem os movimentos. Esse padrão se percebe em outras categorias analisadas, descritas à frente.

Diferentemente do que acontece em @MichelTemer, a intertextualidade é alta aqui. Há presença de discurso direto em quatro dos cinco posts que realizam movimento de fala governamental. Além disso, há oito vocativos-remissões nos tweets. Nesta análise, consideramos vocativo-remissão a inclusão de perfis do Twitter com o símbolo da arroba (@). Esse mecanismo permite que leitoras/es cliquem no vocativo-remissão e acessem o perfil mencionado. Nos textos, dois perfis são mencionados: @MichelTemer, seis vezes, e @JusticaGovBR, duas vezes. Este último é o perfil oficial do Ministério da Justiça no Twitter. Cabe mencionar também a recorrência de links para sites externos à rede social: são cinco links no corpus de nove posts.

Aqui, há coincidência de ocorrência entre movimento retórico da fala governamental, discurso direto e uso de vocativo-remissão, de forma que os posts configuram, à maneira do que é comum no Twitter, um tipo de discurso direto padrão [texto (19)] - ou seja, no Twitter, uma maneira de marcar início do discurso direto é o uso do vocativo-remissão (símbolo “@” + nome do perfil) e sinal de dois-pontos. Num esforço do perfil em manter voz oficial e supostamente imparcial, percebe-se que nos posts que realizam fala governamental na voz direta há maior liberdade de expressão, configurada pela presença de modalidade e de metáforas. 
Figura 20 - Texto (19)

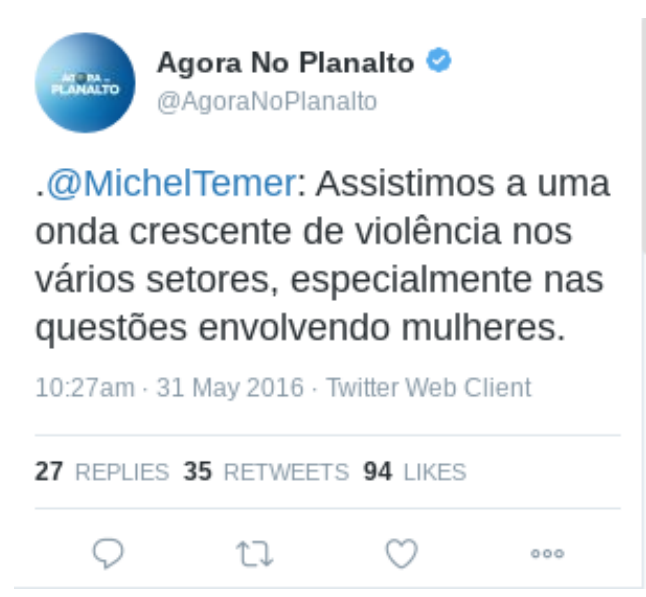

Fonte: printscreen de post do perfil @AgoraNoPlanalto no Twitter

A metáfora "onda crescente" [texto (19)] aparece no sentido de que a violência é uma onda. Ao adotar o termo "onda" para falar sobre vários setores, o post se descola do problema presente, extrapolando-o estrategicamente para o tema mais geral da segurança pública, que é agenda no governo, como já mencionado.

As estruturas textuais presentes nos posts (movimentos retóricos e intertextualidade) se apresentam de forma padronizada. Em quatro das cinco ocorrências de movimento retórico de fala governamental, há o combo discurso direto e vocativo-remissão. Já nos quatro movimentos de comunicado oficial, há uso de links e de vocativo-remissão. Única exceção ao padrão é o post reproduzido no texto (20):

Figura 21 - Texto (20)

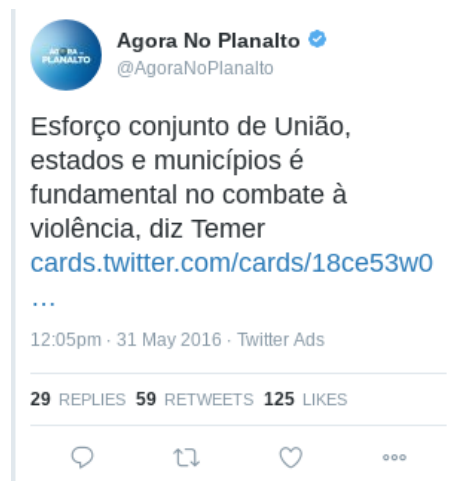

Fonte: printscreen de post do perfil @AgoraNoPlanalto no Twitter

A metáfora bélica ("esforço conjunto" e "em combate"), [texto (20)], remete à agenda governamental explicitada - segurança pública via maior rigor das punições -, que é reforçada pela presença de modalidade alta ("fundamental").

Devemos ressaltar que, das nove postagens, sete apresentam o nome Michel Temer 
ou variações, em abordagem fincada numa estrutura de comunicação que prioriza o personalismo. Isso é ainda mais relevante se for considerado o momento histórico e político em que ocorreram as postagens. $O$ governo interino de Michel Temer era recente, visto que foi empossado em 12 de maio. Único traço da transitoriedade de Temer no cargo de presidente está no último post da sequência de tweets, em que Temer é descrito como presidente interino [texto (21)].

Figura $22-$ Texto (21)

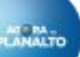

Agora No Planalto

@AgoraNoPlanalto

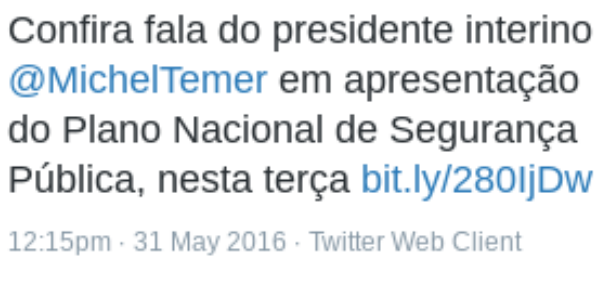

19 REPLIES 55 RETWEETS 94 LIKES

Fonte: printscreen de post do perfil @AgoraNoPlanalto no Twitter

Ressaltamos que, diferentemente das postagens de @MichelTemer, essa é também a única ocorrência da palavra "presidente". Supomos que @AgoraNoPlanalto faz essa escolha tendo em vista seu caráter oficial e governamental. Possivelmente não seria conveniente, nem diplomático - pelo menos em momento inicial -, o perfil demonstrar muita aderência ao novo presidente, em detrimento à presidenta afastada. Por isso, talvez, a falta do termo "presidente". Já o perfil pessoal de Temer se dá essa liberdade.

Como dito, em @MichelTemer há duas menções "Presidente Michel Temer", nos dois posts de 31 de maio, assinados pela assessoria de imprensa. Pode parecer contraditório, mas enxergamos uma estratégia. Ao passo que o perfil oficial da presidência (@AgoraNoPlanalto) aparentemente não escolhe lados no embate político, o perfil pessoal (@MichelTemer) tem direito de facto de mencionar o título "presidente", afinal, interino ou não, Temer estava como presidente desde 12 de maio de 2016. Burlando aparente imparcialidade, @AgoraNoPlanalto faz referência ao perfil @MichelTemer, por meio do vocativo-remissão, seis vezes nas postagens, de forma em que há isenção simulada. O perfil @AgoraNoPlanalto é mais comedido, mas leitoras/es encontram a sugestão de acessar diretamente o perfil @MichelTemer (pelo vocativo-remissão), e lá encontram posicionamento mais incisivo sobre a questão presidencial. 
Figura $23-$ Texto (22)

Agora No Planalto

@Agora NoPlanalto

.@MichelTemer: Da palavra

devemos passar para ação, da

ação devemos passar para a

execução.

10:31am - 31 May 2016 - Twitter Web Client

30 REPLIES 45 RETWEETS 115 LIKES

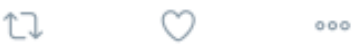

Fonte: printscreen de post do perfil @AgoraNoPlanalto no Twitter

Figura $24-$ Texto (23)

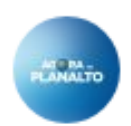

Agora No Planalto $\theta$

@AgoraNoPlanalto

Alexandre de Moraes

(@JusticaGovBR): Estamos

preparando alterações legislativas

em relação à lei de execuções

penais.

10:36am · 31 May 2016 - Twitter Web Client

17 REPLIES 35 RETWEETS 83 LIKES

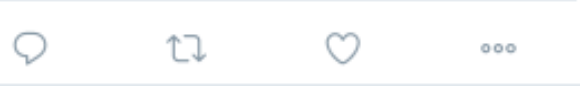

Fonte: printscreen de post do perfil @AgoraNoPlanalto no Twitter

Outra questão de léxico relevante é a frequência em que há referência à adolescente agredida. Há baixíssima frequência: é mencionada uma só vez, no primeiro post da sequência [texto (18)]. Situação idêntica ocorre em @MichelTemer [texto (11)]. Ressaltamos que esses dois posts estabelecem relação: o primeiro postado foi o de @MichelTemer, e o segundo, do @AgoraNoPlanalto, é paráfrase da nota oficial reproduzida no perfil pessoal de Temer.

Já os crimes são descritos como "estupro" e depois retomados indiretamente como "questões envolvendo mulheres" [texto (19)]. Mais uma vez - como destacado em relação a @ThinkOlga e @MichelTemer -, o caso concreto/ particular (estupro coletivo) é extrapolado para tema mais amplo, abstrato/ geral, ou seja, a violência contra mulheres. Sobre o termo 'mulher', ressaltamos que aparece apenas uma vez. Não se fala de violência contra 
mulheres, mas de governo em face " $a$ uma onda crescente de violência nos vários setores, especialmente nas questões envolvendo mulheres". Diferentemente do @ThinkOlga que aproveitou o caso concreto/ particular (o estupro) para extrapolar a pauta para tema abstrato/ geral (violência contra mulheres), @AgoraNoPlanalto preferiu extrapolar para tema muito mais amplo e mais abstrato (de forma que minimiza a violência específica): a violência na sociedade brasileira, o que enseja articulação ao punitivismo e à segurança pública como prioridade política.

Assim, identificamos nos posts de @MichelTemer e @AgoraNoPlanalto pouco engajamento com a causa feminista, com o protagonismo feminino e com o combate à cultura do estupro e do machismo. Característica que se torna perceptível pela ausência de discurso feminista nos posts de @AgoranoPlanalto e @MichelTemer, pelo foco no discurso de direito legal e pelo enquadre do enfrentamento à violência contra mulheres pela ótica da segurança pública, que seria alcançada por meio da união de estados, com propostas de aprimoramento da segurança pública centradas no campo da abstração. Desta maneira, percebemos o esforço de referências ao crime em tela como uma estratégia para angariar confiança da população na solidez do novo governo.

Desta forma, ao passo em que não há marcada preocupação com a vulnerabilidade de mulheres na sociedade, abre-se espaço para promoção de políticas punitivistas e de soluções centradas em ações securitárias. Há, sim, preocupação de endereçar à população e assegurar que "Da palavra devemos passar para a ação, da ação devemos passar para a execução" [texto (22)], e que o governo, representado na área de segurança pelo então ministro da justiça Alexandre de Moraes, estaria "preparando alterações legislativas em relação à (sic) leis de execuções penais" [texto (23)]. Nota-se que a abstração do tema adotada pelo perfil é tal que as promessas de ação descritas são pouco precisas de informação e de conteúdo. Mais uma vez, nota-se a argumentação pelo viés linguístico: palavras pesam mais do que argumentos. $\mathrm{O}$ argumento do post é vazio, mas a escolha de palavras é expressiva. Nos dois excertos destacados, percebe-se discurso punitivista como solução para a "onda crescente de violência". Há também discurso bélico e jurídico. Não há, contudo, discurso feminista, de empoderamento de mulheres ou de conscientização da sociedade sobre os problemas do machismo estrutural.

\section{Considerações}

As análises mostram tendência de expansão do tema: os perfis partem do caso específico/ particular (estupro coletivo) e chegam no caso abstrato/ geral (violência contra mulheres). A tendência permite identificação de estrutura quase análoga à das fábulas infantis, nas quais há uma história concreta para exemplificar um conceito, uma ideia mais abrangente. No caso das manifestações nas redes sociais, o estupro serve como exemplo máximo e gritante da extensão da violência machista da sociedade brasileira contra 
mulheres. A adolescente representa fragilidade do feminino no Brasil.

A expansão do tema tem, contudo, propósitos distintos nos perfis: no @ThinkOlga, o efeito é educar leitoras/es. Em @MichelTemer, existe propósito presumido de transmitir unidade e solidez, relevantes, considerando a novidade da presidência Temer à época. 0 perfil @AgoraNoPlanalto trilha caminho semelhante ao de @MichelTemer, além de exibir marcada ausência de protagonismo feminino em seus posts.

As análises desses três perfis lançam luz sobre a existência de caminhos ideológicos distintos nos dois grupos de fala, sendo que o poder público se afasta do debate feminista, silencia vozes femininas sobre o tema e aponta punição rigorosa como a solução a ser implementada para coibir a violência da sociedade, entendida no modo macro e geral, de modo que mitiga a urgência do debate específico acerca da violência contra mulheres.

\section{Referências}

BLOMMAERT, Jan. Discourse. A critical introduction. Cambridge: Cambridge University Press, 2005. https://doi.org/10.1017/CBO9780511610295

BAKHTIN, Mikhail. Estética da criação verbal. Trad. Maria Ermantina Galvão G. Pereira. São Paulo: Martins Fontes, 1997.

BUENO, Samira; LIMA, Renato Sérgio. 11 Anuário Brasileiro de Segurança Pública 2017. Fórum Brasileiro de Segurança Pública. São Paulo, 2017.

CHOULIARAKI, Lilie; FAIRCLOUGH, Norman. Discourse in late modernity. Edinburgh: Edinburgh University Press, 1999.

FAÚNDES, Anibal et al. (2006). Violência sexual: procedimentos indicados e seus resultados no atendimento de urgência de mulheres vítimas de estupro. Ver. Bras. Ginecol. Obstet., v. 28, n. 2, p. 126-35, 2006. https://doi.org/10.1590/S0100-72032006000200009

FAIRCLOUGH, Norman. Discurso e mudança social. Trad. Izabel Magalhães. Brasília: Editora UnB, 2001.

FAIRCLOUGH, Norman. Analyzing discourse: textual analysis for social research. London; New York: Routledge, 2003. https://doi.org/10.4324/9780203697078

RESENDE, Viviane de Melo. Análise de discurso crítica e etnografia: o Movimento Nacional de Meninos e Meninas de Rua, sua crise e o protagonismo juvenil. 2008. Tese (Doutorado em Linguística) - Instituto de Letras, Universidade de Brasília, Brasília, 2008.

RESENDE, Viviane de Melo. Análise Interdiscursiva de Políticas Públicas: reflexão epistemológica. Ámbitos - Revista Internacional de Comunicação, v. 39, p. 52-64, 2018.

VIEIRA, Viviane Cristina; RESENDE, Viviane de Melo. Análise de discurso (para a) crítica: o texto como material de pesquisa. 2. ed. Campinas: Pontes, 2016.

Recebido em: 10/10/2018

Aceito em: 10/04/2019 